\title{
Low Temperature Synthesis of Belite Cement Based on Silica Fume and Lime
}

\author{
M. A. Tantawy, ${ }^{1}$ M. R. Shatat, ${ }^{2}$ A. M. El-Roudi, ${ }^{1}$ M. A. Taher, ${ }^{2}$ and M. Abd-El-Hamed ${ }^{2}$ \\ ${ }^{1}$ Chemistry Department, Faculty of Science, Minia University, Minia 61111, Egypt \\ ${ }^{2}$ Chemistry Department, Faculty of Science, Al-Azhar University, Assiut 71524, Egypt
}

Correspondence should be addressed to M. A. Tantawy; matantawy75@yahoo.com

Received 17 May 2014; Revised 3 July 2014; Accepted 4 July 2014; Published 29 October 2014

Academic Editor: Tomasz Czujko

Copyright (C) 2014 M. A. Tantawy et al. This is an open access article distributed under the Creative Commons Attribution License, which permits unrestricted use, distribution, and reproduction in any medium, provided the original work is properly cited.

This paper describes the low temperature synthesis of belite $\left(\beta-\mathrm{C}_{2} \mathrm{~S}\right)$ from silica fume. Mixtures of lime, $\mathrm{BaCl}_{2}$, and silica fume with the ratio of $(\mathrm{Ca}+\mathrm{Ba}) / \mathrm{Si}=2$ were hydrothermally treated in stainless steel capsule at $110-150^{\circ} \mathrm{C}$ for $2-5$ hours, calcined at $600-700^{\circ} \mathrm{C}$ for 3 hours, and analyzed by FTIR, XRD, TGA/DTA, and SEM techniques. Dicalcium silicate hydrate (hillebrandite) was prepared by hydrothermal treatment of lime/silica fume mixtures with $(\mathrm{Ca}+\mathrm{Ba}) / \mathrm{Si}=2$ at $110^{\circ} \mathrm{C}$ for 5 hours. Hillebrandite partially dehydrates in two steps at 422 and $508^{\circ} \mathrm{C}$ and transforms to $\gamma-\mathrm{C}_{2} \mathrm{~S}$ at $734^{\circ} \mathrm{C}$ which in turn transforms to $\alpha^{\prime}-\mathrm{C}_{2} \mathrm{~S}$ at $955^{\circ} \mathrm{C}$ which in turn transforms to $\beta-\mathrm{C}_{2} \mathrm{~S}$ when cooled. In presence of $\mathrm{Ba}^{2+}$ ions, $\beta-\mathrm{C}_{2} \mathrm{~S}$ could be stabilized with minor transformation to $\gamma-\mathrm{C}_{2} \mathrm{~S}$. Mixture of silica fume, lime, and $\mathrm{BaCl}_{2}$ with the ratio of $(\mathrm{Ca}+\mathrm{Ba}) / \mathrm{Si}=2$ was successfully utilized for synthesis of $\beta-\mathrm{C}_{2} \mathrm{~S}$ by hydrothermal treatment at $110^{\circ} \mathrm{C}$ for 5 hours followed by calcination of the product at $700^{\circ} \mathrm{C}$ for 3 hours.

\section{Introduction}

Portland cement is a hydraulic binder forming a paste with water, which sets and hardens due to hydration reactions [1]. The main constituent of Portland cements is clinker, which itself is composed of $40-80 \mathrm{wt} . \%$ tricalcium silicate $3 \mathrm{CaO} \cdot \mathrm{SiO}_{2}$ (alite, $\mathrm{C}_{3} \mathrm{~S}$ ), $10-50 \mathrm{wt} . \%$ dicalcium silicate $2 \mathrm{CaO} \cdot \mathrm{SiO}_{2}$ (belite, $\mathrm{C}_{2} \mathrm{~S}$ ), $0-15 \mathrm{wt} . \%$ tricalcium aluminate $3 \mathrm{CaO} \cdot \mathrm{Al}_{2} \mathrm{O}_{2}$ (aluminate, $\mathrm{C}_{3} \mathrm{~A}$ ), and $0-20 \mathrm{wt} . \%$ tetracalcium aluminoferrite $4 \mathrm{CaO} \cdot \mathrm{Al}_{2} \mathrm{O}_{3} \cdot \mathrm{SiO}_{2}$ (ferrite, $\mathrm{C}_{4} \mathrm{AF}$ ) [2]. Alite and belite determine most of the adhesive properties, strength, and durability of Portland cement. Both alite and belite show the same physical and mechanical properties after complete hydration but the former hydrates much faster [3]. Cement industry is responsible for approximately $5 \%$ of total $\mathrm{CO}_{2}$ emissions [4]. About $900-1000 \mathrm{~kg} \mathrm{CO}$ per tonne of clinker is released due to calcination of $\mathrm{CaCO}_{3}$ and fuel combustion $[2,5]$. The demand for thermal energy equals $\sim 3000-4000 \mathrm{MJ} /$ tonne of clinker for dry process [2]. Additionally, $324-540 \mathrm{MJ} /$ tonne of cement of electrical energy is required for grinding of raw materials and cement [6]. The production temperature of belite is lower than that of alite. In contrast, belite has low reactivity than alite, rendering it much less useful. The high reactivity of alite is related to the reactive sites around its more ionic oxygen atoms that are not contained in belite [7]. Attempt to improve the reactivity of belite phase in order to reduce energy requirements for cement production is one of the most important challenges.

Belite has five polymorphs $\left(\beta, \gamma, \alpha, \alpha_{\mathrm{H}}^{\prime}\right.$, and $\left.\alpha_{\mathrm{L}}^{\prime}\right)$ undergoing reversible temperature dependent transformations as illustrated in Figure 1 [8]. The $\alpha_{\mathrm{H}}^{\prime}, \alpha_{\mathrm{L}}^{\prime}$, and $\beta$ polymorphs are derived from the $\alpha$ form by a decrease of the symmetry due to the disorder of $\mathrm{SiO}_{4}{ }^{-4}$ groups and slight changes in the position of $\mathrm{Ca}$ atoms [9]. The $\alpha^{\prime}$-polymorphs are the most hydraulic forms of belite. $\beta$-belite is also a hydraulic but less hydraulic than the $\alpha^{\prime}$-polymorphs. $\gamma$-belite is a nonhydraulic polymorph and does not account for the setting and hardening of cement. $\beta$-belite is the most common polymorph in industrial Portland cement clinker [10]. $\gamma-\mathrm{C}_{2} \mathrm{~S}$ crystals are less dense (more voluminous) than $\beta-\mathrm{C}_{2} \mathrm{~S}$ crystals, which causes cracking of other $\beta-C_{2} S$ crystals, forming voluminous powder and dust. Dusting phenomenon can be prevented if $\beta-C_{2} S$ is stabilized by fast cooling and/or by inclusion of stabilizing ions. $\mathrm{Fe}^{3+}, \mathrm{Al}^{3+}, \mathrm{Mg}^{2+}, \mathrm{Zn}^{2+}, \mathrm{Cr}^{3+}, \mathrm{Pb}^{2+}, \mathrm{B}^{3+}$, 


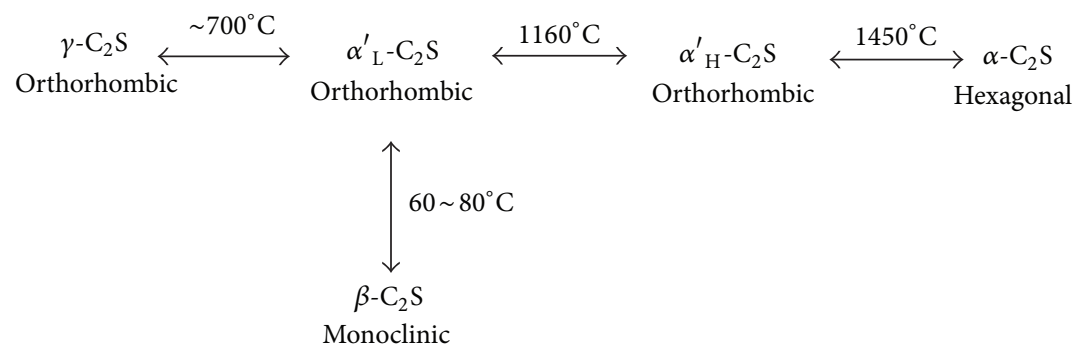

Figure 1: Polymorphs of belite.

$\mathrm{Na}^{+}$, and $\mathrm{K}^{+}$can replace calcium and/or silicon atoms in the structure and reduce the $\mathrm{Ca} / \mathrm{Si}$ ratio of $\beta-\mathrm{C}_{2} \mathrm{~S}$ to less than 2 $[11,12]$. Reactivity and hydraulic properties of stabilized $\beta$ $\mathrm{C}_{2} \mathrm{~S}$ depend on the type and amount of the stabilizing ions [13]. On the other hand, fast cooling may produce fine $\beta$ $\mathrm{C}_{2} \mathrm{~S}$ crystals affording $\beta-\gamma-\mathrm{C}_{2} \mathrm{~S}$ transformation, even without the need for stabilizer [14]. Based on density functional theory calculations, stabilizing ions modify charge density localization of the electronic structure of $\mathrm{C}_{2} \mathrm{~S}$ and enhance the reactivity and in turn would broaden the applicability of $\mathrm{C}_{2} \mathrm{~S}$ [7].

Synthesis of low-energy belite cement as an alternative to the conventional Portland cement was carried out in two steps. The first step is preparation of dicalcium silicate hydrate (hillebrandite, $\mathrm{Ca}_{2}\left(\mathrm{SiO}_{3}\right)(\mathrm{OH})_{2}$ ) by hydrothermal treatment of silica rich waste material/lime mixtures. Hillebrandite was synthesized by hydrothermal treatment of quartz and lime with $\mathrm{Ca} / \mathrm{Si}=2.0$ at $200^{\circ} \mathrm{C}$ for 10 hours or at $250^{\circ} \mathrm{C}$ for 5 hours [15]. The main silicate anion structure of hillebrandite studied by ${ }^{29} \mathrm{Si}$ MAS NMR analysis is a mixture of a dimer and a single-chain polymer (larger than $\mathrm{Si}_{5} \mathrm{O}_{16}$ ) and that polymerization advanced with an increase of the synthesizing temperature [16]. Different polymorphs of calcium silicate hydrates with $\mathrm{Ca} / \mathrm{Si}=2.0$, namely, $\alpha-\mathrm{C}_{2} \mathrm{SH}\left[\mathrm{Ca}_{2}\left(\mathrm{SiO}_{4} \mathrm{H}\right) \mathrm{OH}\right]$, dellaite $\left[\mathrm{Ca}_{6} \mathrm{Si}_{3} \mathrm{O}_{11}(\mathrm{OH})_{2}\right]$, and hillebrandite, were synthesized and their stability and phase transformation were investigated under hydrothermal conditions up to $400^{\circ} \mathrm{C}$. $\alpha$ $\mathrm{C}_{2} \mathrm{SH}$ completely transforms to dellaite at $350^{\circ} \mathrm{C}$ for 1 hour which in turn undergoes a reversible phase transformation to hillebrandite at low temperatures below $300^{\circ} \mathrm{C}$ [17]. Hillebrandite was synthesized by mechanochemical treatment of amorphous precipitated silica/lime using a vibration mill at room temperature [18]. The second step involves calcination of hillebrandite to prepare belite. Hillebrandite starts to decompose at about $500^{\circ} \mathrm{C}$ producing low-crystalline $\beta-\mathrm{C}_{2} \mathrm{~S}$ [15]. Moreover, ${ }^{29} \mathrm{Si}$ MAS NMR analysis illustrates that the temperature at which $\beta-C_{2} S$ begins to form decreases as the $\mathrm{Ca} / \mathrm{Si}$ ratio of hillebrandite becomes higher [19] or as the temperature of hydrothermal synthesis of hillebrandite becomes higher [16]. On the other hand, XRD analysis illustrates that the crystallographic properties and density of dissociation products of $\alpha-\mathrm{C}_{2} \mathrm{SH}$ depend on the calcination temperature [20]. $\alpha-\mathrm{C}_{2} \mathrm{SH}$ dissociates at $390-490^{\circ} \mathrm{C}$ forming an intermediate phase plus $\gamma-\mathrm{C}_{2} \mathrm{~S}$. The intermediate phase then transforms to $\alpha_{\mathrm{L}}^{\prime}$ phase at $920-960^{\circ} \mathrm{C}$ and yields $\beta-\mathrm{C}_{2} \mathrm{~S}$ on cooling while hillebrandite yields $\beta-\mathrm{C}_{2} \mathrm{~S}$ at the lowest temperature [21]. Hillebrandite synthesized by mechanochemical treatment of amorphous precipitated silica/lime decomposed into $\beta-\mathrm{C}_{2} \mathrm{~S}$ below $1000^{\circ} \mathrm{C}$ [18].

The reactivity of $\beta-C_{2} S$ relates to its large specific surface area taking into consideration the fact that the hydration is chemical-reaction-rate-controlled until its completion [19]. The specific surface area of $\beta-C_{2} S$ depends on calcination temperature of hillebrandite. The hydration rate of $\beta-C_{2} S$ enhanced with increasing surface area. The specific surface area affects the hydration reaction mechanism. In the case of specific areas of $5.5 \mathrm{~m}^{2} / \mathrm{g}$ or less, the reaction changes from a chemical reaction to a diffusion-controlled one [22]. The hydration rate of $\beta-C_{2} S$ enhances with raising curing temperature of hydration [23]. The hydration rate of $\beta-C_{2} S$ enhanced with dynamic more than static hydration condition [24]. At early ages of hydration, $\beta-\mathrm{C}_{2} \mathrm{~S}$ yields $\mathrm{C}-\mathrm{S}-\mathrm{H}$ with a $\mathrm{Ca} / \mathrm{Si}$ ratio of 1.81 plus $\mathrm{Ca}(\mathrm{OH})_{2}$. At later ages, $\mathrm{C}-\mathrm{S}-\mathrm{H}$ and $\mathrm{Ca}(\mathrm{OH})_{2}$ react to form a C-S-H(II)-like monophase hydrate having a $\mathrm{Ca} / \mathrm{Si}$ ratio of 1.98 with different morphology [24]. The hydration rate of the $\beta-C_{2} S$ also enhances with increasing water/solid ratio [25]. Recent works presented alternative cements containing higher amounts of $\beta-C_{2} S$ in their composition based upon the use of waste materials such as rice hull and husk ash as well as coal fly ash $[15,26$, 27]. Silica fume is an abundant material produced in many countries as a waste product from silicon industry around the world containing approximately $90-97 \%$ os $\mathrm{SiO}_{2}$. Silica fume have average particle size $<1 \mu \mathrm{m}$, specific surface area of 13$30 \mathrm{~m}^{2} / \mathrm{g}$, and specific gravity of 2.22 . Reuse of waste materials seems to be a good approach to solve both economic and environmental issues related to cement production [28-30]. This work describes a method for the production of $\beta-C_{2} S$ from silica fume.

\section{Materials and Experimental Techniques}

Freshly prepared lime was prepared by calcination of limestone powder (purity > 99\%) in an electrical muffle furnace at $950^{\circ} \mathrm{C}$ for 3 hours. Lime was cooled to room temperature in desiccator, milled, and stored in tightly closed plastic bottle to avoid carbonation. Silica fume was purchased from Ferrosilicon Company, Edfo, Egypt. Distilled water and analytical grade barium chloride were used without further 
TABLE 1: Mixtures of silica fume and lime with and without $\mathrm{BaCl}_{2}$ hydrothermally treated and calcined at different conditions.

\begin{tabular}{ll}
\hline Number & Hydrothermal treatment conditions \\
\hline 1 & Silica fume, lime treated at $110^{\circ} \mathrm{C}$ for 2 hours \\
2 & Silica fume, lime with $\mathrm{BaCl}_{2}$ treated at $110^{\circ} \mathrm{C}$ for 2 hours \\
3 & Silica fume, lime treated at $110^{\circ} \mathrm{C}$ for 5 hours \\
4 & Silica fume, lime with $\mathrm{BaCl}_{2}$ treated at $110^{\circ} \mathrm{C}$ for 5 hours \\
5 & Silica fume, lime treated at $150^{\circ} \mathrm{C}$ for 2 hours \\
6 & Silica fume, lime with $\mathrm{BaCl}_{2}$ treated at $150^{\circ} \mathrm{C}$ for 2 hours \\
7 & Silica fume, lime treated at $150^{\circ} \mathrm{C}$ for 5 hours \\
8 & Silica fume, lime with $\mathrm{BaCl}_{2}$ treated at $150^{\circ} \mathrm{C}$ for 5 hours \\
\hline
\end{tabular}

purification. Preparation of hillebrandite by hydrothermal treatment of silica fume and lime with and without $2 \mathrm{wt} \%$ $\mathrm{BaCl}_{2}$ was carried out as described below. Mixtures of silica fume and lime with and without $\mathrm{BaCl}_{2}$ keeping the ratio $\mathrm{Ca} / \mathrm{Si}$ or $(\mathrm{Ca}+\mathrm{Ba}) / \mathrm{Si}=2.0$ were hydrothermally treated at 110 or $150^{\circ} \mathrm{C}$ for 2 or 5 hours as illustrated in Table 1.

Mixtures of silica fume, lime, and $\mathrm{BaCl}_{2}$ were added to distilled water at water/solid ratio of $5 / 1$ by weight in stainless steel capsule keeping the occupied volume equal to 0.67 of the total volume capacity. The capsule was tightly closed to avoid sealing of water vapor. The capsule was shacked to obtain homogeneous suspension inside. The capsule was heated in electric oven for appropriate temperature and time. At the end of the hydrothermal treatment process, the capsule was removed from oven and cooled to room temperature. The product of hydrothermal treatment (hillebrandite) was filtered, washed with distilled water, and dried under vacuum. Preparation of $\beta-C_{2} S$ was carried out by calcination of hillebrandite in an electric muffle furnace at 600 or $700^{\circ} \mathrm{C}$ for 3 hours. At the end calcination process, the calcined product $\left(\beta-\mathrm{C}_{2} \mathrm{~S}\right)$ was cooled to room temperature in desiccator, milled, and stored in tightly closed plastic bottles. X-ray fluorescence XRF and X-ray diffraction XRD analyses were carried out by Philips X-ray diffractometer PW 1370 Co. with Ni filtered $\mathrm{CuK}_{\alpha}$ radiation (1.5406 ̊). The Fourier transform infrared FTIR analysis was measured by spectrometer Perkin Elmer FTIR System Spectrum X in the range of $400-4000 \mathrm{~cm}^{-1}$ with spectral resolution of $1 \mathrm{~cm}^{-1}$. Scanning electron microscopy SEM was investigated by JeolDsm 5400 LG apparatus. The thermogravimetric TGA and differential thermogravimetric analyses DTG were carried out with the aid of Shimadzu Corporation thermoanalyzer with DTG-60H detector with $10^{\circ} \mathrm{C} / \mathrm{min}$ heating rate from room temperature up to $1000^{\circ} \mathrm{C}$; under nitrogen atmosphere at $40 \mathrm{~mL} / \mathrm{min}$ flow rate, the hold time at the appropriate temperature is zero.

\section{Results and Discussion}

3.1. Characterization of Starting Materials. Figure 2 illustrates the XRD patterns of limestone and silica fume. Table 2 illustrates the chemical composition of limestone and silica fume inferred by XRF. The chemical composition results confirm XRD results indicating that limestone is mainly

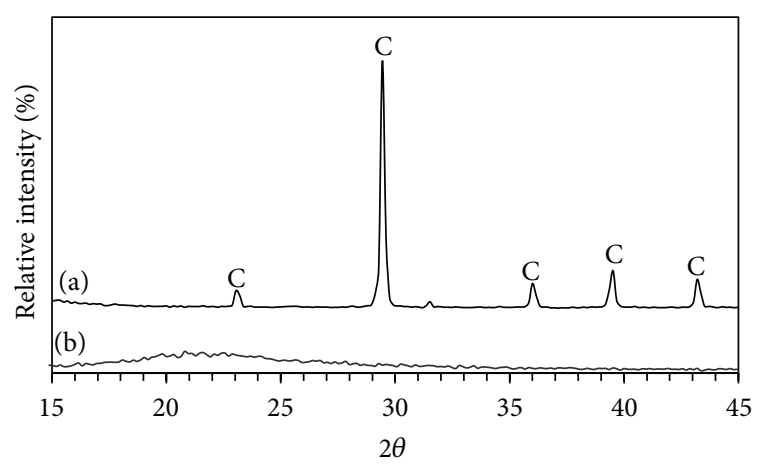

FIGURE 2: XRD patterns of (a) limestone and (b) silica fume (where $\mathrm{C}$ is calcite).

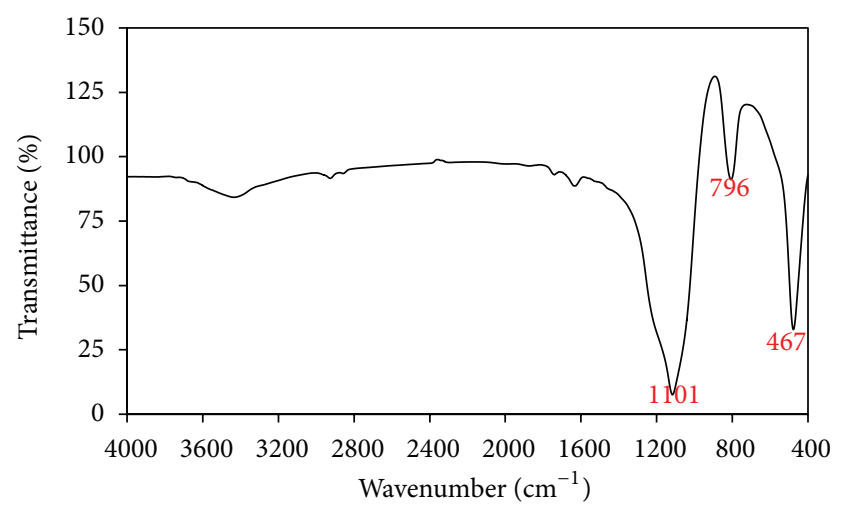

FIGURE 3: FTIR spectrum of silica fume.

composed of calcite $\left(\mathrm{CaCO}_{3}\right)$ while silica fume is mainly composed of amorphous silica as indicated by a broad hump at around $20-25^{\circ} 2 \theta$. Figure 3 illustrates the FTIR spectrum of silica fume. The most significant absorption bands of silica appear at 1101, 796, and $467 \mathrm{~cm}^{-1}$ corresponding to asymmetric stretching vibration of $\mathrm{Si}-\mathrm{O}-\mathrm{Si}$, symmetric stretching vibration of $\mathrm{Si}-\mathrm{O}-\mathrm{Si}$, and bending vibration of $\mathrm{O}-\mathrm{Si}-\mathrm{O}$, respectively [31]. Figure 4 illustrates the SEM micrograph of silica fume. Silica fume has a refined microstructure of high surface area containing silica microspheres.

3.2. Preparation of Hillebrandite. Figures 5 and 6 illustrate the FTIR spectra of lime/silica mixture hydrothermally treated at $110-150^{\circ} \mathrm{C}$ for $2-5$ hours. Hydrothermal treatment initiates the reaction between lime and reactive silica leading to the formation of intermediate calcium silicates hydrate (hillebrandite) which gives rise to strong absorption band at $950 \mathrm{~cm}^{-1}$ (vibrations of $\mathrm{SiO}_{4}^{-4}$ groups) and strong absorption bands at 2530, 1800, and $330 \mathrm{~cm}^{-1}$ [32]. Unreacted silica gives rise to its absorption band at 1101 ( $\mathrm{Si}-\mathrm{O}-\mathrm{Si}$ asymmetric stretching vibration) [31] and unreacted lime gives rise to its absorption band at 3643 and $1450-1500 \mathrm{~cm}^{-1}$ (vibrations of $\mathrm{OH}$ group and $\mathrm{Ca}-\mathrm{O}$ stretching vibration) [32]. Calcite arising from partial carbonation of unreacted lime gives its absorption bands at 2530,1800,1420,840, and $700 \mathrm{~cm}^{-1}$ [33]. The existence of unreacted lime and silica indicates 
TABLE 2: The chemical composition of limestone and silica fume inferred by XRF.

\begin{tabular}{lcccccccccc}
\hline Material & $\mathrm{SiO}_{2}$ & $\mathrm{Al}_{2} \mathrm{O}_{3}$ & $\mathrm{Fe}_{2} \mathrm{O}_{3}$ & $\mathrm{CaO}$ & $\mathrm{MgO}$ & $\mathrm{SO}_{3}$ & $\mathrm{Na}_{2} \mathrm{O}$ & $\mathrm{K}_{2} \mathrm{O}$ & L.O.I & Total \\
\hline Limestone & 0.26 & 0.16 & 0.00 & 54.59 & 0.29 & 0.05 & 0.11 & 0.03 & 43.72 & 99.21 \\
Silica fume & 92.90 & 1.10 & 0.82 & 0.42 & 0.52 & 0.00 & 0.64 & 1.12 & 1.56 & 99.08 \\
\hline
\end{tabular}

TABLE 3: Result of thermal analysis.

\begin{tabular}{|c|c|c|c|c|c|}
\hline Number & Phases & $\begin{array}{c}\text { Temperature } \\
\left({ }^{\circ} \mathrm{C}\right) \\
\end{array}$ & $\begin{array}{c}\text { Peak temperature } \\
\left({ }^{\circ} \mathrm{C}\right)\end{array}$ & $\begin{array}{l}\text { Weight loss } \\
(\%)\end{array}$ & $\begin{array}{c}\text { Weight loss } \\
\text { (mg) }\end{array}$ \\
\hline 1 & Loss of absorbed water & $30-287$ & 109 & 6.85 & 0.555 \\
\hline 2 & Hillebrandite partial dehydration & $288-590$ & 422,508 & 2.53 & 0.205 \\
\hline 3 & $\begin{array}{l}\text { Hillebrandite complete dehydration } \\
\text { (formation of } \gamma-C_{2} S \text { ) }\end{array}$ & $593-781$ & 734 & 19.6 & 1.60 \\
\hline 4 & $\gamma-\mathrm{C}_{2} \mathrm{~S} \rightarrow \alpha^{\prime}-\mathrm{C}_{2} \mathrm{~S}$ transformation & $850-985$ & 955 & - & - \\
\hline Total & & & & 28.98 & 2.36 \\
\hline
\end{tabular}

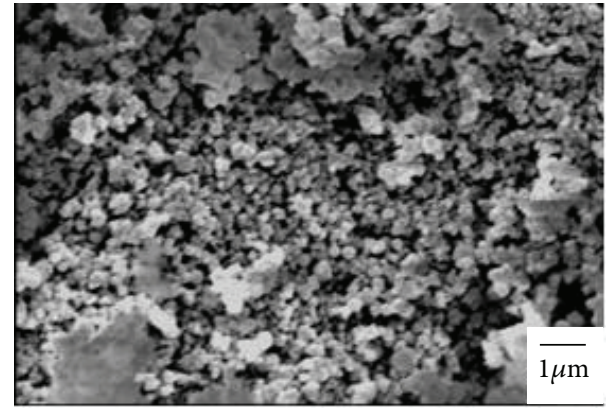

FIGURE 4: SEM micrograph of silica fume.

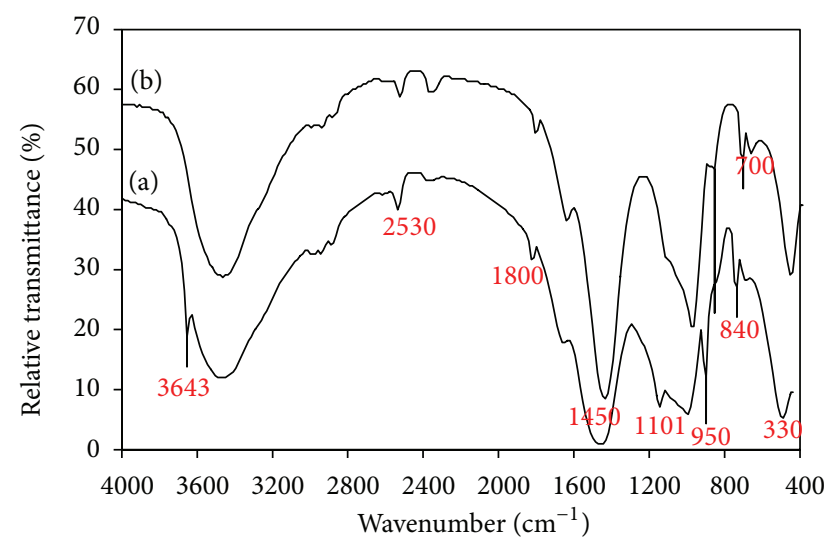

FIGURE 5: FTIR spectra of lime/silica mixture hydrothermally treated at $110^{\circ} \mathrm{C}$ for (a) 2 hours (b) 5 hours.

that the hydrothermal treatment of the lime/silica mixture $(\mathrm{Ca} / \mathrm{Si}=2 / 1)$ at $110^{\circ} \mathrm{C}$ for 2 hours does not drive the reaction to completion. FTIR indicates that the chance of formation hillebrandite was improved by increase of both time (Figure 5) and temperature (Figure 6) of hydrothermal treatment. This is confirmed by disappearance of lime and the decreasing amount of unreacted silica. From economic point of view, the best conditions (heating at $110^{\circ} \mathrm{C}$ for 5 hours)

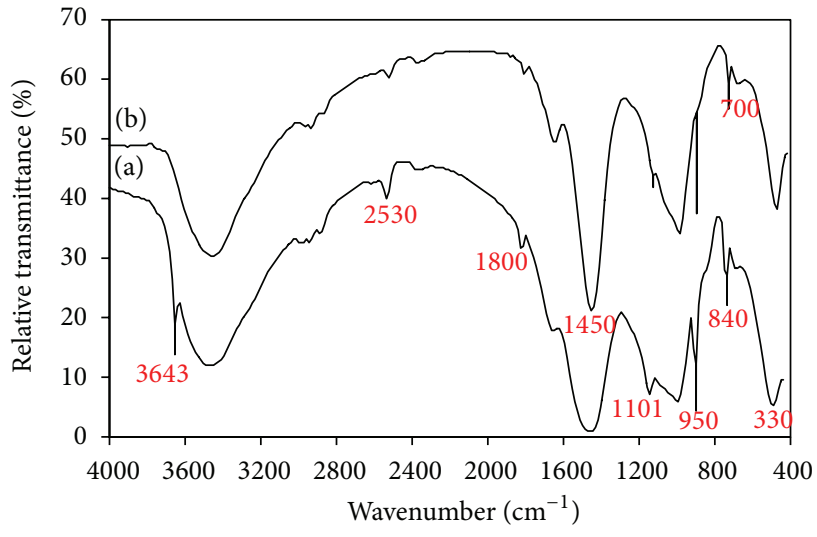

FIGURE 6: FTIR spectra of lime/silica mixture hydrothermally treated for 2 hours at (a) $110^{\circ} \mathrm{C}$ (b) $150^{\circ} \mathrm{C}$.

were selected for the hydrothermal treatment of silica/lime mixtures.

Figure 7 illustrates TGA/DTA thermogram of lime/silica mixture hydrothermally treated at $110^{\circ} \mathrm{C}$ for 5 hours. Result of thermal analysis was illustrated in Table 3. Hillebrandite lost absorbed water at $109^{\circ} \mathrm{C}$. Hillebrandite partially dehydrated in two steps at 422 and $508^{\circ} \mathrm{C}$. Hillebrandite completely dehydrated forming $\gamma-\mathrm{C}_{2} \mathrm{~S}$ at $734^{\circ} \mathrm{C}$. Finally, $\gamma-\mathrm{C}_{2} \mathrm{~S}$ transformed to $\alpha^{\prime}-\mathrm{C}_{2} \mathrm{~S}$ at $955^{\circ} \mathrm{C}$ [34]. When allowed to cool to room temperature, $\alpha^{\prime}-\mathrm{C}_{2} \mathrm{~S}$ may transform $\beta-\mathrm{C}_{2} \mathrm{~S}$ instead of $\gamma-\mathrm{C}_{2} \mathrm{~S}$ as illustrated in Figure 1. Fast cooling and presence of $\mathrm{Ba}^{2+}$ ions may stabilize $\beta-C_{2} S[13]$.

3.3. Preparation of Belite. Figure 8 illustrates the FTIR spectra of lime/silica mixture hydrothermally treated at $110^{\circ} \mathrm{C}$ for 5 hours and calcined at $600-700^{\circ} \mathrm{C}$ for 3 hours. As determined by TGA/DTA results, hillebrandite completely dehydrates forming $\alpha^{\prime}-C_{2} S$ that transforms to $\beta-C_{2} S$ and/or $\gamma-C_{2} S$ after cooling. $\mathrm{C}_{2} \mathrm{~S}$ gives rise to the following absorption bands: three maxima at 1000,910 , and $840 \mathrm{~cm}^{-1}$ ( $\mathrm{Si}-\mathrm{O}$ asymmetric stretching modes), medium intensity band at $430 \mathrm{~cm}^{-1}$ (Si-O bending mode), and a strong band at $530 \mathrm{~cm}^{-1}$ (Si-O-Si out 


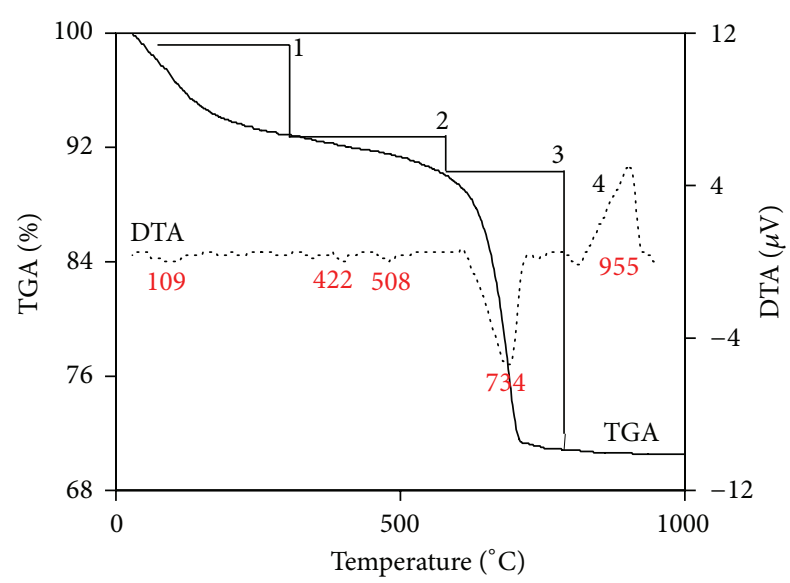

Figure 7: TGA/DTA thermogram of lime/silica mixture hydrothermally treated at $110^{\circ} \mathrm{C}$ for 5 hours.

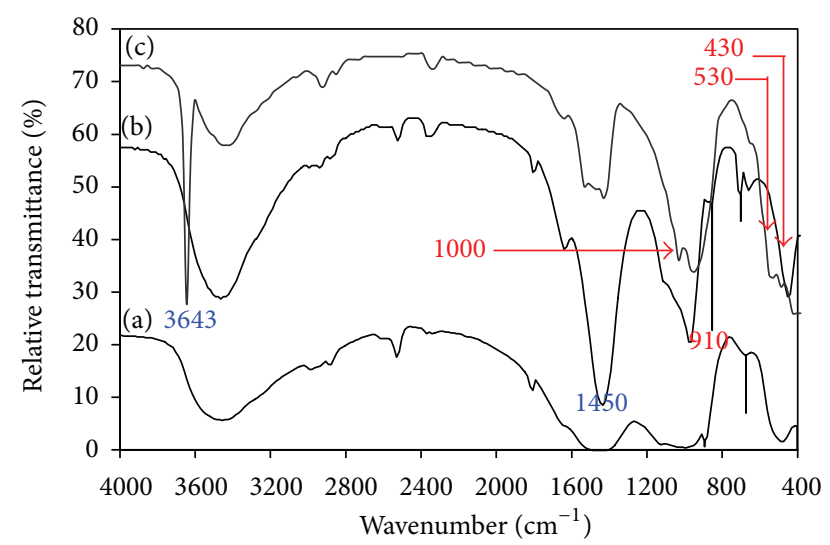

FIGURE 8: FTIR spectra of lime/silica mixture hydrothermally treated at $110^{\circ} \mathrm{C}$ for 5 hours (a) before calcination, (b) calcined at $600^{\circ} \mathrm{C}$, and (c) calcined at $700^{\circ} \mathrm{C}$.

of plane bending mode) [35-37]. $\mathrm{C}_{2} \mathrm{~S}$ does not clearly appear in sample that was calcined at $600^{\circ} \mathrm{C}$ (Figure $8(\mathrm{~b})$ ) but clearly appears in sample that was calcined at $700^{\circ} \mathrm{C}$ (Figure $8(\mathrm{c})$ ). In general, formation of $\mathrm{C}_{2} \mathrm{~S}$ was accompanied by liberation of lime (absorption bands at 3643 and $1450-1500 \mathrm{~cm}^{-1}$ ). This confirms the TGA/DTA results which show that hillebrandite completely dehydrated forming $\gamma-\mathrm{C}_{2} \mathrm{~S}$ at $734^{\circ} \mathrm{C}$.

Figure 9 illustrates XRD patterns of lime/silica mixture hydrothermally treated at $110^{\circ} \mathrm{C}$ for 5 hours calcined at $600-700^{\circ} \mathrm{C}$ for 3 hours. Hillebrandite does not appear in the XRD analysis (Figure 9(a)) because of its gel structure. $\mathrm{C}_{2} \mathrm{~S}$ does not appear in the sample that was calcined at $600^{\circ} \mathrm{C}$ (Figure 9(b)). The mixture of $\gamma-\mathrm{C}_{2} \mathrm{~S}$ (major) and $\beta$ $\mathrm{C}_{2} \mathrm{~S}$ (minor) appears in the sample that was calcined at $700^{\circ} \mathrm{C}$ (Figure $9(\mathrm{c})$ ). This proves that $\beta-\mathrm{C}_{2} \mathrm{~S}$ was not stabilized by fast cooling and transforms to $\gamma-\mathrm{C}_{2} \mathrm{~S}[11,12]$. Figure 10 illustrates XRD patterns of (lime $+\mathrm{BaCl}_{2}$ )/silica mixture hydrothermally treated at $110^{\circ} \mathrm{C}$ for 5 hours calcined at $600-$ $700^{\circ} \mathrm{C}$ for 3 hours. In this case, the situation is reversed. The mixture of $\beta-C_{2} S$ (major) and $\gamma-C_{2} S$ (minor) appears in the sample that was calcined at $700^{\circ} \mathrm{C}$ (Figure $10(\mathrm{~b})$ ). This

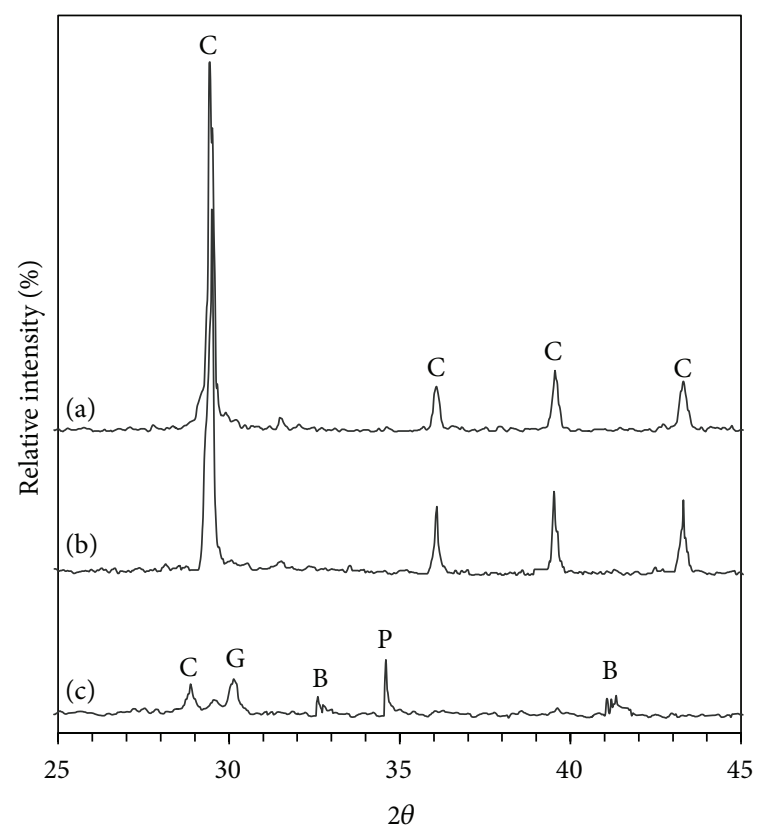

FIGURE 9: XRD patterns of lime/silica mixture hydrothermally treated at $110^{\circ} \mathrm{C}$ for 5 hours (a) before calcination, (b) calcined at $600^{\circ} \mathrm{C}$, and (c) calcined at $700^{\circ} \mathrm{C}$ (where $\mathrm{C}$ is calcite, $\mathrm{P}$ is portlandite, $\mathrm{G}$ is $\gamma-\mathrm{C}_{2} \mathrm{~S}$, and $\mathrm{B}$ is $\beta-\mathrm{C}_{2} \mathrm{~S}$ ).

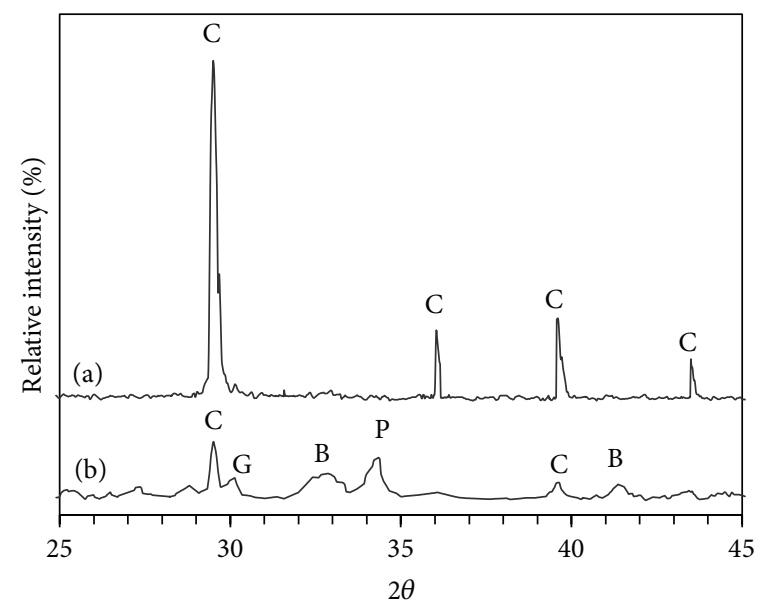

FIgURE 10: XRD patterns of (lime $+\mathrm{BaCl}_{2}$ )/ silica mixture hydrothermally treated at $110^{\circ} \mathrm{C}$ for 5 hours and then calcined for 3 hours at (a) $600^{\circ} \mathrm{C}$ and (b) $700^{\circ} \mathrm{C}$ (where $\mathrm{C}$ is calcite, $\mathrm{P}$ is portlandite, $\mathrm{G}$ is $\gamma-\mathrm{C}_{2} \mathrm{~S}$, and $B$ is $\beta-C_{2} S$ ).

indicates that $\beta-\mathrm{C}_{2} \mathrm{~S}$ was stabilized by $\mathrm{Ba}^{2+}$ ions with minor transformation to $\gamma-\mathrm{C}_{2} \mathrm{~S}$. In other words, $\mathrm{Ba}^{2+}$ ions replace calcium and/or silicon atoms and hence it stabilizes the structure of belite and prevents the transformation of $\beta-\mathrm{C}_{2} \mathrm{~S}$ to $\gamma-\mathrm{C}_{2} \mathrm{~S}[13]$.

Figures 11 and 12 illustrate the SEM micrographs of mixture of silica fume and lime hydrothermally treated at $110-150^{\circ} \mathrm{C}$ for $2-5$ hours. The mixtures of silica fume and lime that were hydrothermally treated at $110^{\circ} \mathrm{C}$ for 2 hours 


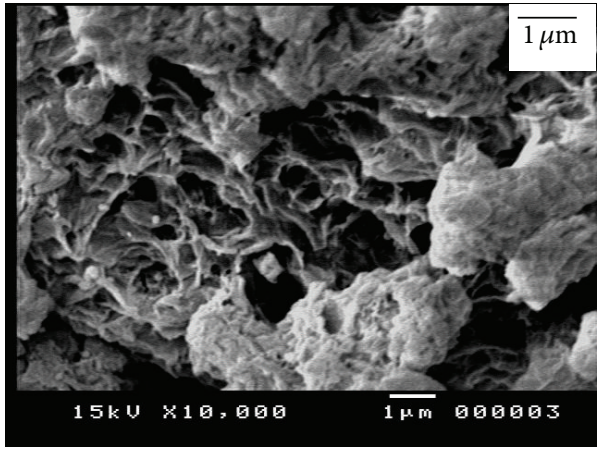

(a)

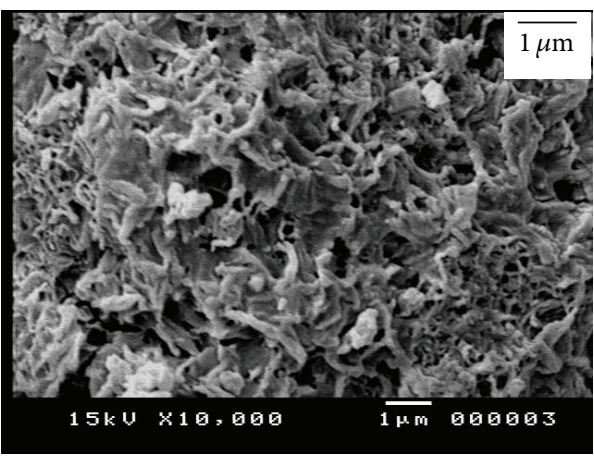

(c)

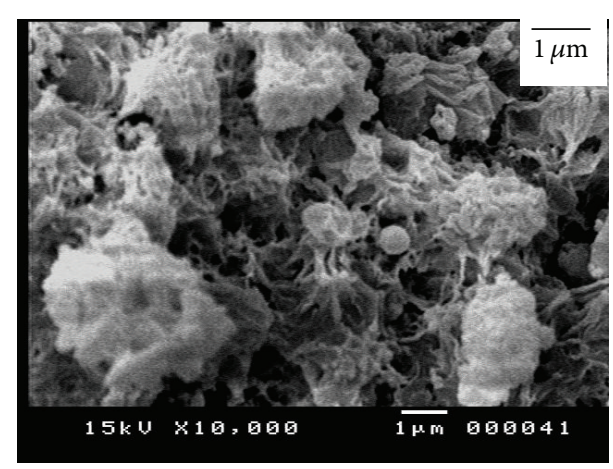

(b)

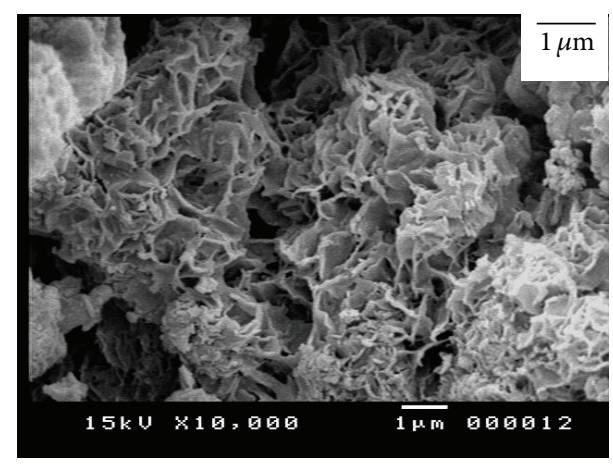

(d)

FIGURE 11: SEM micrographs of mixture of silica fume and lime hydrothermally treated at $110^{\circ} \mathrm{C}$ for (a) 2 hours without $\mathrm{BaCl}_{2}$, (b) 2 hours with $\mathrm{BaCl}_{2}$, (c) 5 hours without $\mathrm{BaCl}_{2}$, and (d) 5 hours with $\mathrm{BaCl}_{2}$.

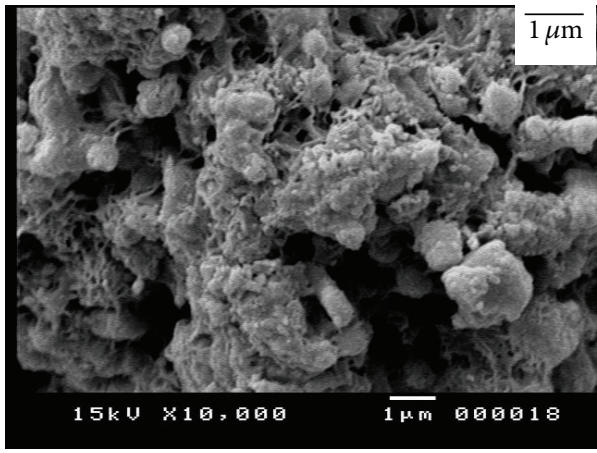

(a)

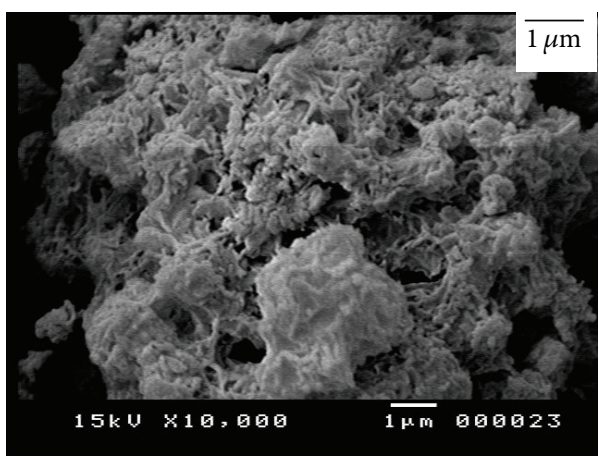

(c)

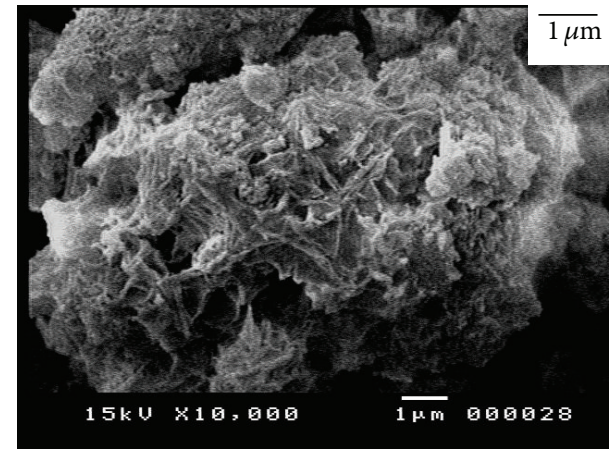

(b)

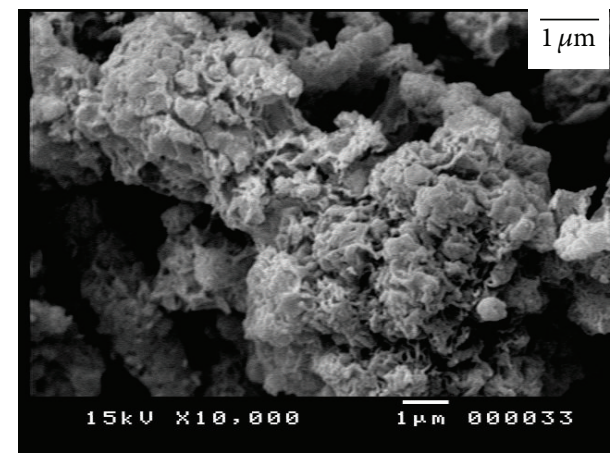

(d)

FIGURE 12: SEM micrographs of mixture of silica fume and lime hydrothermally treated at $150^{\circ} \mathrm{C}$ for (a) 2 hours without $\mathrm{BaCl}_{2}$, (b) 2 hours with $\mathrm{BaCl}_{2}$, (c) 5 hours without $\mathrm{BaCl}_{2}$, and (d) 5 hours with $\mathrm{BaCl}_{2}$. 


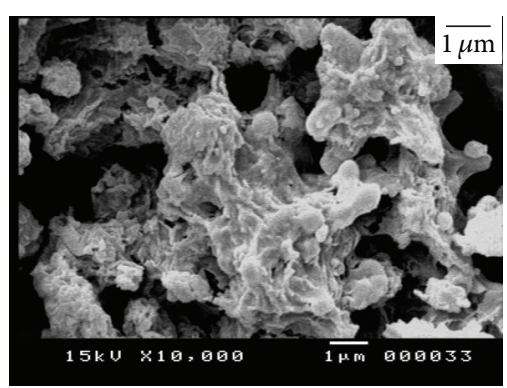

(a)

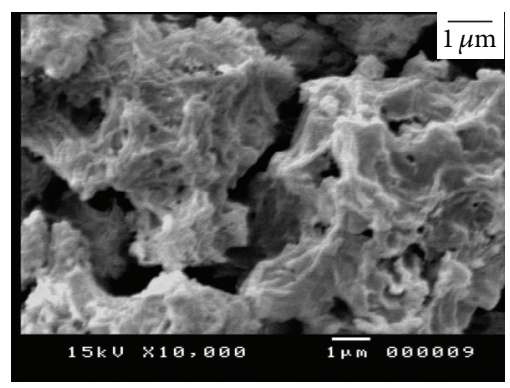

(b)

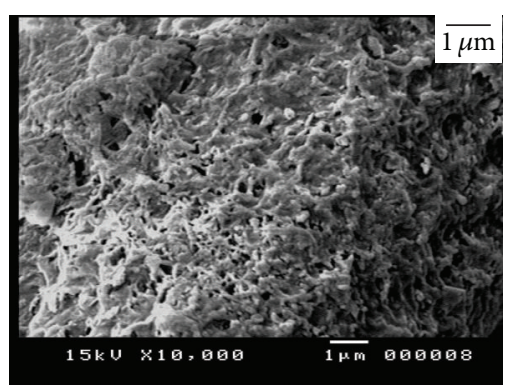

(c)

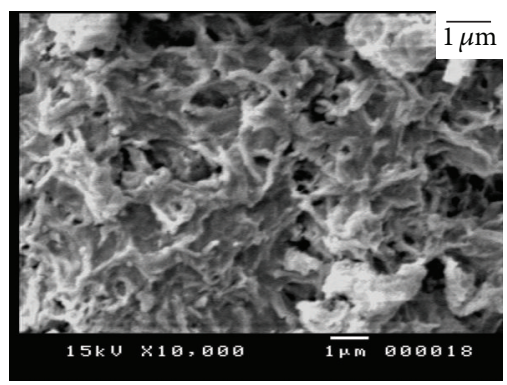

(d)

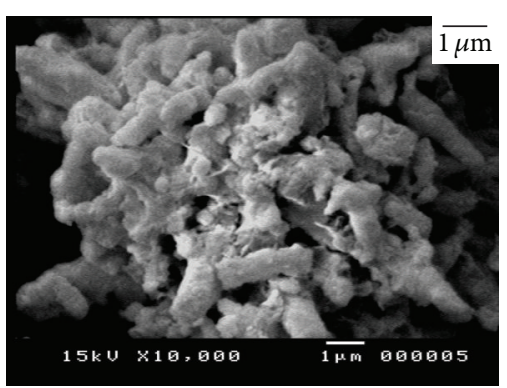

$\left(a^{\prime}\right)$

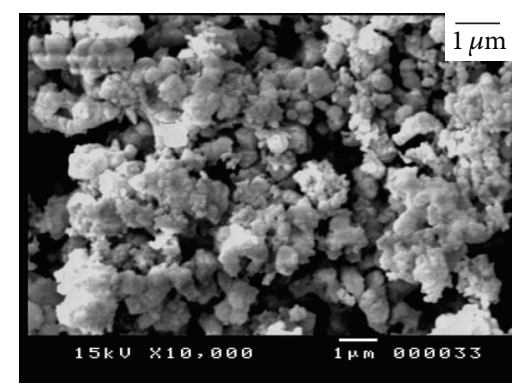

$\left(b^{\prime}\right)$

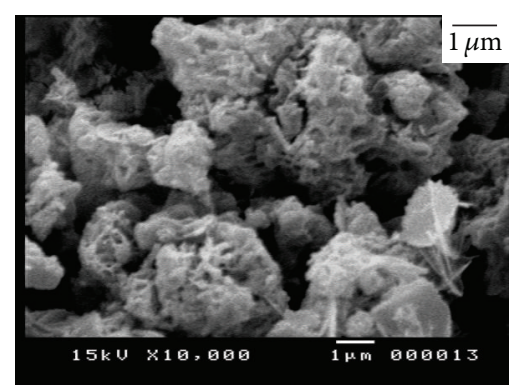

$\left(c^{\prime}\right)$

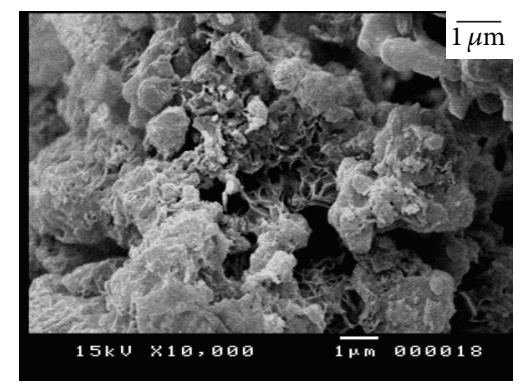

$\left(\mathrm{d}^{\prime}\right)$

FIGURE 13: SEM micrographs of mixture of silica fume and lime represented in Figure 11 after being calcined at $600^{\circ} \mathrm{C}$ (right) and $700^{\circ} \mathrm{C}($ left).

contain little amount of hillebrandite of low density with weblike morphology (Figures 11(a) and 11(b)). On the other hand, the mixtures that were hydrothermally treated at $110^{\circ} \mathrm{C}$ for 5 hours contain higher amount of hillebrandite of low density with web-like morphology (Figures $11(\mathrm{c})$ and $11(\mathrm{~d})$ ). The morphology of the hillebrandite greatly changes with raising the temperature of the hydrothermal treatment. The mixtures of silica fume and lime that were hydrothermally treated at $150^{\circ} \mathrm{C}$ for $2-5$ hours with/without $\mathrm{BaCl}_{2}$ addition contain high amount of short fibrous hillebrandite of high density
(Figures 12(a)-12(d)). Figure 13 illustrates the SEM micrographs of mixtures of silica fume and lime hydrothermally treated at $110^{\circ} \mathrm{C}$ for $2-5$ hours after being calcined at $600-$ $700^{\circ} \mathrm{C}$. As determined by TGA/DTA results, mixtures that were calcined at $600^{\circ} \mathrm{C}$ contain partially dehydrated calcium silicate with glass-like morphology (Figures 13(a)-13(d)). On the other hand, mixtures of silica fume and lime that were calcined at $700^{\circ} \mathrm{C}$ contain fine $\beta-\mathrm{C}_{2} \mathrm{~S}$ crystals (Figures $13\left(\mathrm{a}^{\prime}\right)$ and $\left.13\left(c^{\prime}\right)\right)$. The amount of fine $\beta-C_{2} S$ crystals markedly increases in case of mixture of silica fume and lime with $\mathrm{BaCl}_{2}$ 


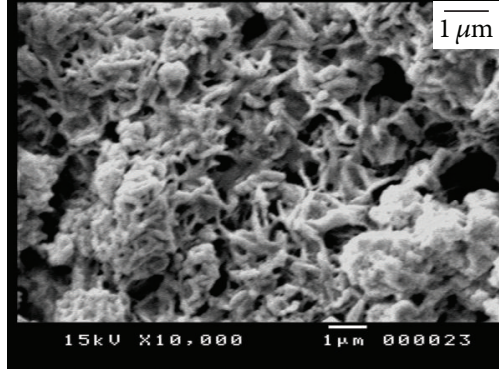

(a)

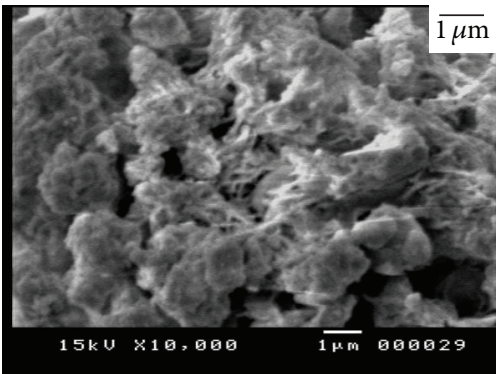

(b)

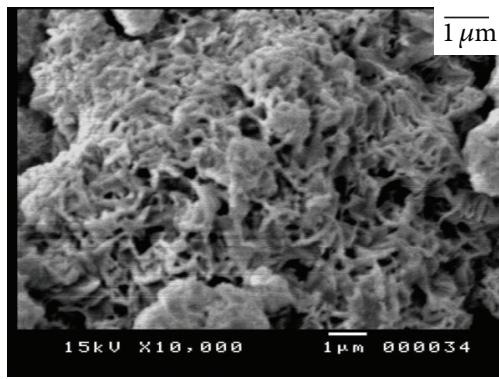

(c)

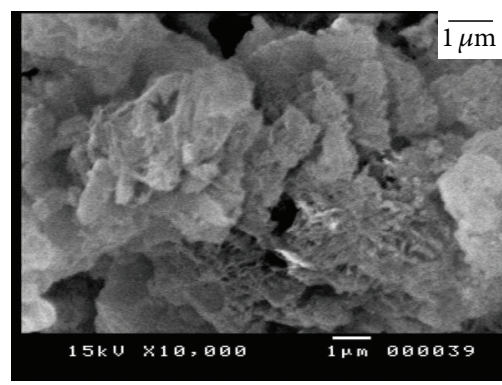

(d)

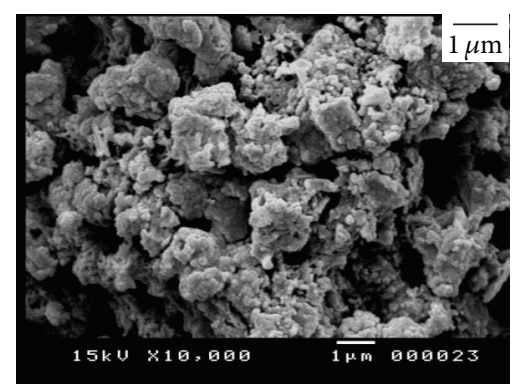

$\left(\mathrm{a}^{\prime}\right)$

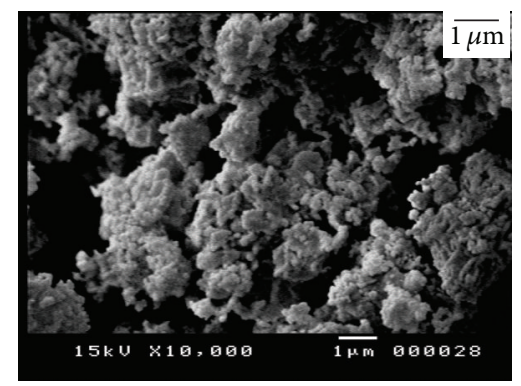

$\left(b^{\prime}\right)$

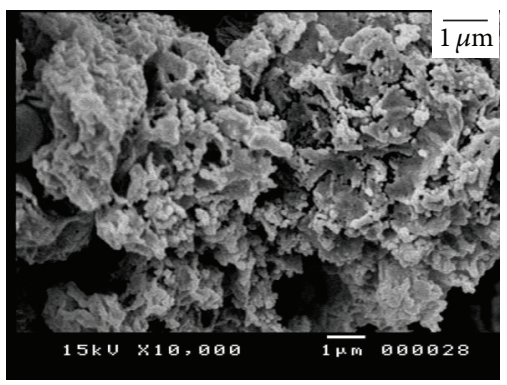

$\left(c^{\prime}\right)$

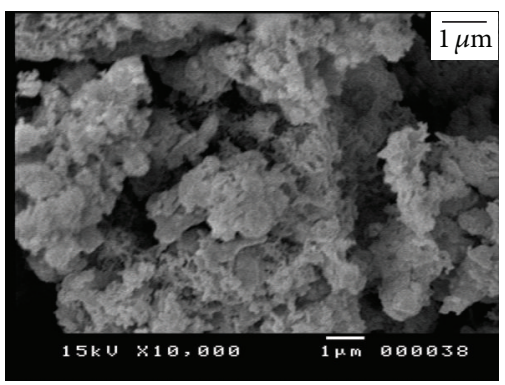

$\left(d^{\prime}\right)$

FIGURE 14: SEM micrographs of mixture of silica fume and lime represented in Figure 12 after being calcined at $600^{\circ} \mathrm{C}$ (right) and $700^{\circ} \mathrm{C}($ left).

addition (Figures $13\left(\mathrm{~b}^{\prime}\right)$ and $\left.13\left(\mathrm{~d}^{\prime}\right)\right)$. This confirms TGA/DTA results. Figure 14 illustrates the SEM micrographs of mixtures of silica fume and lime hydrothermally treated at $150^{\circ} \mathrm{C}$ for $2-$ 5 hours after being calcined at $600-700^{\circ} \mathrm{C}$. Mixtures that were calcined at $600^{\circ} \mathrm{C}$ still contain partially dehydrated calcium silicate with glass-like morphology (Figures 14(a)-14(d)). The amount of fine $\beta-\mathrm{C}_{2} \mathrm{~S}$ crystals formed in mixtures that were calcined at $700^{\circ} \mathrm{C}$ is not affected by raising the temperature of the hydrothermal treatment even in presence of $\mathrm{BaCl}_{2}$ addition (Figures $14\left(\mathrm{a}^{\prime}\right)$ and $14\left(\mathrm{~d}^{\prime}\right)$ ).

\section{Conclusions}

The following is concluded.

(1) FTIR results show that hillebrandite was successfully prepared by hydrothermal treatment of lime/silica 
fume mixtures with $(\mathrm{Ca}+\mathrm{Ba}) / \mathrm{Si}=2$ at $110^{\circ} \mathrm{C}$ for 5 hours.

(2) TGA/DTA results show that hillebrandite partially dehydrates in two steps at 422 and $508^{\circ} \mathrm{C}$ and transforms to $\gamma-\mathrm{C}_{2} \mathrm{~S}$ at $734^{\circ} \mathrm{C}$ that in turn transforms to $\alpha^{\prime}$ $\mathrm{C}_{2} \mathrm{~S}$ at $955^{\circ} \mathrm{C}$.

(3) XRD results show that $\alpha^{\prime}-\mathrm{C}_{2} \mathrm{~S}$ transforms to $\beta$ $\mathrm{C}_{2} \mathrm{~S}$ upon cooling. In absence of $\mathrm{Ba}^{2+}$ ions, $\beta-\mathrm{C}_{2} \mathrm{~S}$ undergoes major transformation to $\gamma-\mathrm{C}_{2} \mathrm{~S}$. Whereas, in presence of $\mathrm{Ba}^{2+}$ ions, $\beta-\mathrm{C}_{2} \mathrm{~S}$ could be stabilized with formation of little amount of $\gamma-\mathrm{C}_{2} \mathrm{~S}$.

(4) Mixture of silica fume, lime, and $\mathrm{BaCl}_{2}$ with the ratio of $(\mathrm{Ca}+\mathrm{Ba}) / \mathrm{Si}=2$ was successfully utilized for synthesis of $\beta-C_{2} S$ by hydrothermal treatment at $110^{\circ} \mathrm{C}$ for 5 hours followed by calcination of the product at $700^{\circ} \mathrm{C}$ for 3 hours.

\section{Conflict of Interests}

The authors declare that they have no conflict of interests regarding the publication of this paper.

\section{References}

[1] J. P. Jackson, "Portland cement: classification and manufacture," in Lea's Chemistry of Cement and Concrete, P. C. Hewlett, Ed., p. 25, Butterworth-Heinemann, Oxford, UK, 4th edition, 2007.

[2] "EIPPCB (European Integrated Pollution Prevention and Control Bureau). Reference Document on Best Available Techniques in Cement, Lime and Magnesium Oxide Manufacturing Industries, European Commission," 2010.

[3] J. F. Young and S. Mindess, Concrete, Prentice-Hall, Upper Saddle River, NJ, USA, 1981.

[4] E. Worrell, L. Price, N. Martin, C. Hendriks, and L. O. Meida, "Carbon dioxide emissions from the global cement industry," Annual Review of Energy and the Environment, vol. 26, pp. 303329, 2001

[5] H. G. Van Oss and A. C. Padovani, "Cement manufacture and the environment. Part II. Environmental challenges and opportunities," Journal of Industrial Ecology, vol. 7, no. 1, pp. 93126, 2003.

[6] V. Johansen and T. V. Kouznetsova, "Clinker formation and new processes," in Proceedings of the 9th International Congress on the Chemistry of Cement, New Delhi, India, 1992.

[7] E. Durgun, H. Manzano, R. J. M. Pellenq, and J. C. Grossman, "Understanding and controlling the reactivity of the calcium silicate phases from first principles," Chemistry of Materials, vol. 24, no. 7, pp. 1262-1267, 2012.

[8] R. Sakurada, A. K. Singh, T. M. Briere, M. Uzawa, and Y. Kawazoe, "Crystal structure analysis of dicalcium silicates by Ab-initio calculation," in Proceedings of the 32nd Conference on Our World in Concrete and Structures, pp. 28-29, Singapore, 2007.

[9] X. J. Feng, X. M. Min, and C. X. Tao, "Study on the structure and characteristic of dicalcium silicate with quantum chemistry calculations," Cement and Concrete Research, vol. 24, no. 7, pp. 1311-1316, 1994.

[10] S. Telschow, Clinker burning kinetics and mechanism [Ph.D. thesis], Department of Chemical and Biochemical Engineering,
Combustion and Harmful Emission Control Research Centre, Technical University of Denmark, 2012.

[11] G. C. Bye, Portland Cement Composition, Production and Preparation, Pergamon Press, Oxford, UK, 1st edition, 1983.

[12] H. F. Taylor, Cement Chemistry, Thomas Telford Publishing, London, UK, 2nd edition, 1997.

[13] C. J. Chan, W. M. Kriven, and J. F. Young, "Physical stabilization of the $\beta-\gamma$ transformation in dicalcium silicate," Journal of the American Ceramic Society, vol. 75, no. 6, pp. 1621-1627, 1992.

[14] V. K. Peterson, Diffraction investigations of cement and tricalcium silicate using Rietveld analysis [Ph.D. thesis], Department of Chemistry, Materials and Forensic Sciences University of Technology, Sydney, Australia, 2003.

[15] H. Ishida, K. Mabuch, K. Sasaki, and T. Mitsuda, "Lowtemperature synthesis of $\beta-\mathrm{Ca}_{2} \mathrm{SiO}_{4}$ from hillebrandite," Journal of the American Ceramic Society, vol. 75, no. 9, pp. 2427-2432, 1992.

[16] Y. Okada, K. Sasaki, B. Zhong, H. Ishida, and T. Mitsuda, "Formation processes of $\beta-\mathrm{C}_{2} \mathrm{~S}$ by the decomposition of hydrothermally prepared C-S- $\mathrm{H}$ with $\mathrm{Ca}(\mathrm{OH})_{2}$," Journal of the American Ceramic Society, vol. 77, no. 5, pp. 1319-1323, 1994.

[17] X. Hu, K. Yanagisawa, A. Onda, and K. Kajiyoshi, "Stability and phase relations of dicalcium silicate hydrates under hydrothermal conditions," Journal of the Ceramic Society of Japan, vol. 114, no. 1326, pp. 174-179, 2006.

[18] K. Sasaki, T. Masuda, H. Ishida, and T. Mitsuda, "Synthesis of calcium silicate hydrate with $\mathrm{Ca} / \mathrm{Si}=2$ by mechanochemical treatment," Journal of the American Ceramic Society, vol. 80, no. 2, pp. 472-476, 1997.

[19] Y. Okada, H. Ishida, K. Sasaki, J. F. Young, and T. Mitsuda, "Characterization of C-S-H from highly reactive $\beta$-dicalcium silicate prepared from hillebrandite," Journal of the American Ceramic Society, vol. 77, no. 5, pp. 1313-1318, 1994.

[20] M. Miyazaki, S. Yamazaki, K. Sasaki, H. Ishida, and H. Toraya, "Crystallographic data of a new phase of dicalcium silicate," Journal of the American Ceramic Society, vol. 81, no. 5, pp. 13391343, 1998.

[21] H. Ishida, S. Yamazaki, K. Sasaki, Y. Okada, and T. Mitsuda, " $\alpha$-Dicalcium silicate hydrate: Preparation, decomposed phase, and its hydration," Journal of the American Ceramic Society, vol. 76, no. 7, pp. 1707-1712, 1993.

[22] K. Sasaki, H. Ishida, Y. Okada, and T. Mitsuda, "Highly reactive $\beta$-dicalcium silicate: $\mathrm{V}$, influence of specific surface area on hydration," Journal of the American Ceramic Society, vol. 76, no. 4, pp. 870-874, 1993.

[23] H. Ishida, K. Sasaki, Y. Okada, and T. Mitsuda, "Highly reactive $\beta$-dicalcium silicate: III, hydration behavior at $40-80^{\circ} \mathrm{C}$," Journal of the American Ceramic Society, vol. 75, no. 9, pp. 25412546, 1992.

[24] H. Ishida, K. Sasaki, A. Mizuno, Y. Okada, and T. Mitsuda, "Highly reactive $\beta$-dicalcium silicate: IV, ball-milling and static hydration at room temperature," Journal of the American Ceramic Society, vol. 75, no. 10, pp. 2779-2784, 1992.

[25] H. Ishida, K. Sasaki, and T. Mitsuda, "Highly reactive $\beta$ dicalcium silicate: I, hydration behavior at room temperature," Journal of the American Ceramic Society, vol. 75, no. 2, pp. 353358, 1992.

[26] F. A. Rodrigues and P. J. M. Monteiro, "Hydrothermal synthesis of cements from rice hull ash," Journal of Materials Science Letters, vol. 18, no. 19, pp. 1551-1552, 1999. 
[27] W. Jiang and D. M. Roy, "Hydrothermal processing of new fly ash cement," American Ceramic Society Bulletin, vol. 71, no. 4, pp. 642-647, 1992.

[28] P. Arjunan, M. R. Silsbee, and D. M. Roy, "Sulfoaluminate-belite cement from low-calcium fly ash and sulfur-rich and other industrial by-products," Cement and Concrete Research, vol. 29, no. 8, pp. 1305-1311, 1999.

[29] A. Öztürk, Y. Suyadal, and H. Oǧuz, "The formation of belite phase by using phosphogypsum and oil shale," Cement and Concrete Research, vol. 30, no. 6, pp. 967-971, 2000.

[30] A. Guerrero, S. Goñi, A. Macías, and M. P. Luxán, "Hydraulic activity and microstructural characterization of new fly ashbelite cements synthesized at different temperatures," Journal of Materials Research, vol. 14, no. 6, pp. 2680-2687, 1999.

[31] K. Baltakys, R. Jauberthie, R. Siauciunas, and R. Kaminskas, "Influence of modification of $\mathrm{SiO}_{2}$ on the formation of calcium silicate hydrate," Materials Science, vol. 25, no. 3, pp. 663-670, 2007.

[32] F. A. Rodrigues, "Synthesis of cements from rice hull," American Chemical Society, vol. 39, no. 2, pp. 30-31, 1999.

[33] H. Böke, Ö. Çizer, B. Ipekoğlu, E. Uǧurlu, K. Şerifaki, and G. Toprak, "Characteristics of lime produced from limestone containing diatoms," Construction and Building Materials, vol. 22, no. 5, pp. 866-874, 2008.

[34] C. A. S. Oliveira, A. G. Gumieri, A. M. Gomes, and W. L. Vasconcelos, "Characterization of magnesium slag aiming the utilization as a mineral admixture in mortar," in International RILEM Conference on the Use of Recycled Materials in Building and Structures, pp. 919-924, 2004.

[35] W. Eitel, Silicate Science, Volume I: Silicate Structures, Academic Press, New York, NY, USA, 1964.

[36] M. Y. A. Mollah, W. Yu, R. Schennach, and D. L. Cocke, "Fourier transform infrared spectroscopic investigation of the early hydration of Portland cement and the influence of sodium lignosulfonate," Cement and Concrete Research, vol. 30, no. 2, pp. 267-273, 2000.

[37] F. A. Rodrigues, "Synthesis of chemically and structurally modified dicalcium silicate," Cement and Concrete Research, vol. 33 , no. 6, pp. 823-827, 2003. 

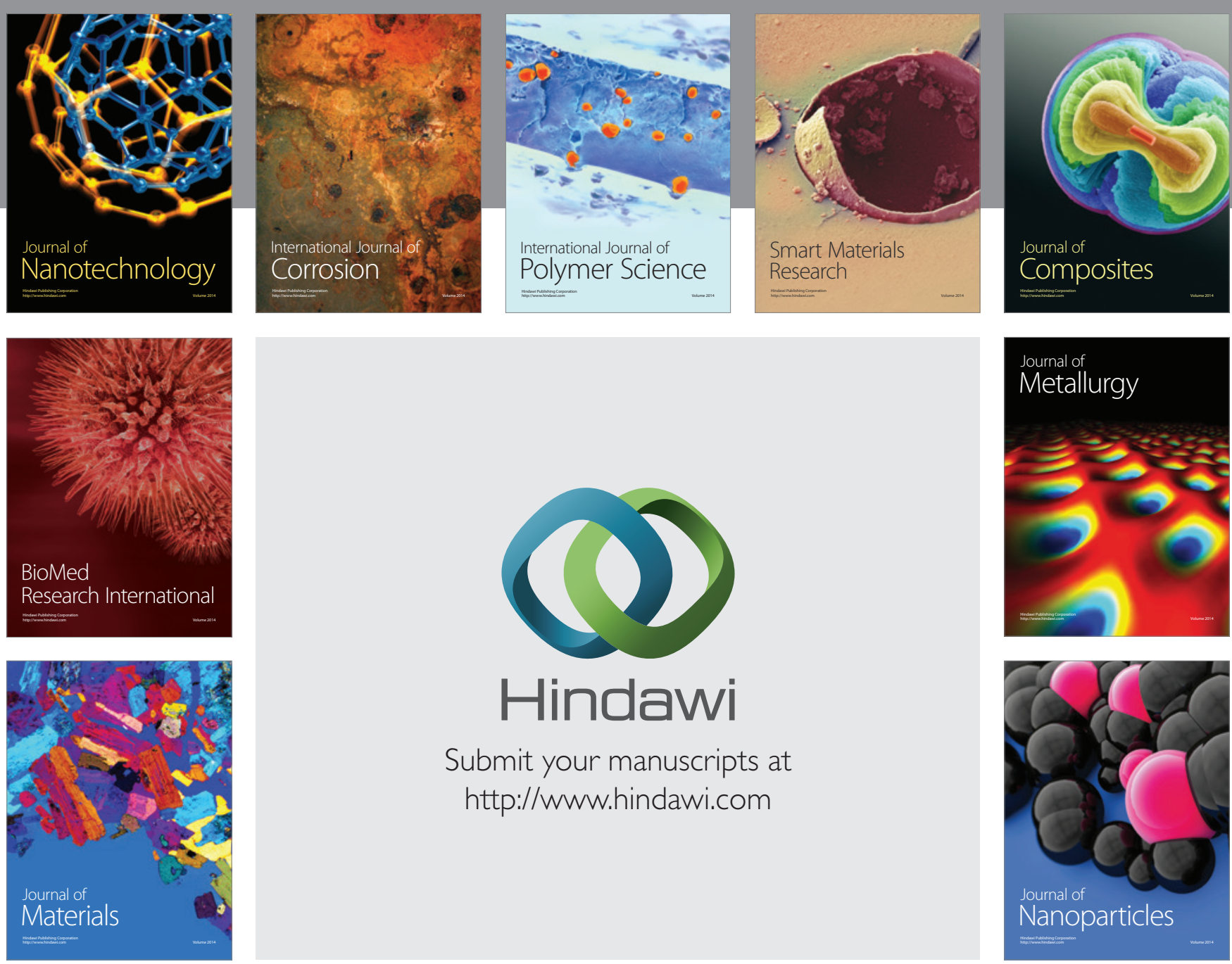

Submit your manuscripts at http://www.hindawi.com
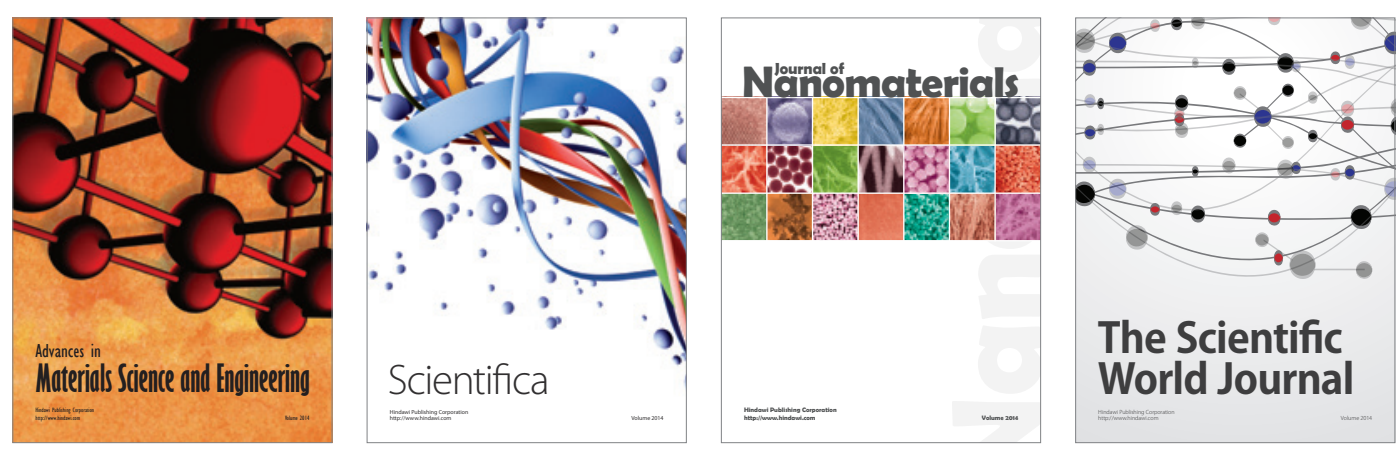

\section{The Scientific World Journal}
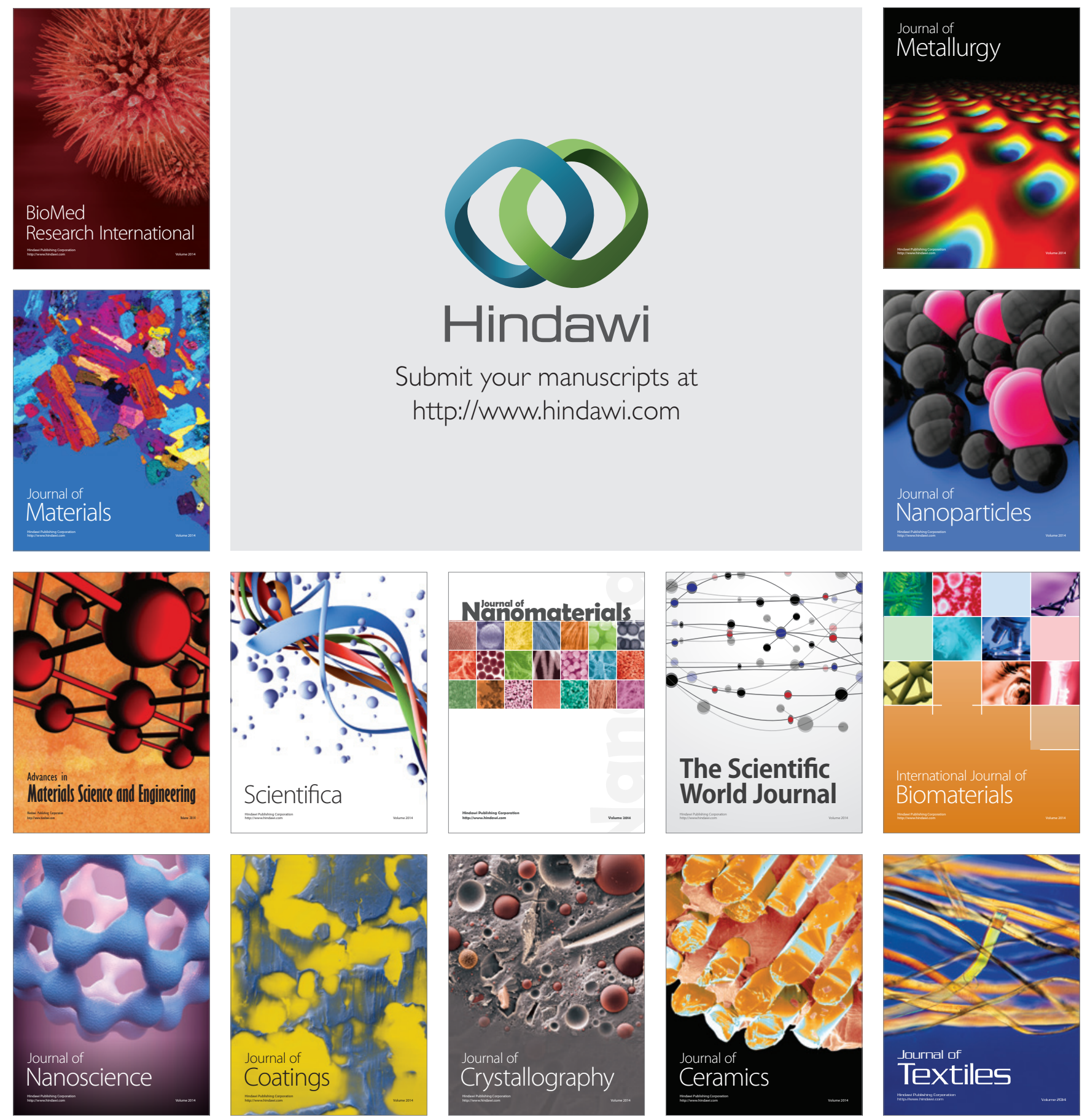